\title{
Infection characteristics of Himasthla elongata cercariae in cockles as a function of water current
}

\author{
X. de Montaudouin ${ }^{1, *}$, A. M. Wegeberg ${ }^{2}$, K. T. Jensen ${ }^{2}$, P. G. Sauriau ${ }^{3}$ \\ ${ }^{1}$ Laboratoire d'Océanographie Biologique, UMR 5805 Université Bordeaux 1 - CNRS, 2 rue du Pr Jolyet, F-33120 Arcachon, France \\ ${ }^{2}$ Department of Marine Ecology, Institute of Biological Sciences, University of Aarhus, Finlandsgade 14, DK-8200 Aarhus N, \\ Denmark \\ ${ }^{3}$ CREMA (CNRS-IFREMER), BP 5, F-17137 L'Houmeau, France
}

\begin{abstract}
Digenean trematodes are widespread parasites of marine fauna. The first intermediate host of Himasthla elongata (Echinostomatidae) is the periwinkle Littorina littorea. The second host is less specific, as it includes various bivalve species. The definitive host is a waterbird. The free-living cercaria acts to ensure transmission from the first and second intermediate hosts. We examined the impact of water flow (still and running water) and host size $[6-8,8-10,10-12 \mathrm{~mm}$ shell length classes) on the settling success of $H$. elongata cercariae in the second intermediate host by utilizing the common cockle Cerastoderma edule. Under 2 scenarios (free-stream velocity of 0 and $6 \mathrm{~cm} \mathrm{~s}^{-1}$ ) more than $90 \%$ of the experimental population of cockles (90 individuals per replicate) acquired infections and $60 \%$ of the added cercariae were recovered as metacercariae in cockle tissue (mainly foot and siphons). Infection intensity increased significantly with cockle size. Considering the filtering capacity of cockles, the dimension of the flume, and the flow velocity, a passive infection mechanism is proposed based on the suspension feeding activity of the host organism. The scale of potential dispersal of $H$. elongata is at least a few hundred metres.
\end{abstract}

KEY WORDS: Cerastoderma edule - Cercariae - Dispersion - Flume - Himasthla elongata - Metacercariae - Transmission efficiency - Trematode

\section{INTRODUCTION}

Marine bivalve species from near-coastal areas including estuaries and intertidal flats are generally hosts to various digenean trematodes that frequently occur with high prevalence in bivalve populations (Lauckner 1971, 1983, 1987, 1994, Sousa 1991). Individual bivalves are also often heavily parasitized with larval trematodes (Lauckner 1971, 1983, Jonsson \& André 1992). Some trematodes can be significant pathogens of their intermediate hosts either by producing outright mortalities or by inducing behavioural changes in the host organisms which makes them vulnerable to predation by definitive hosts including birds or fish (Johnson 1968, Hulscher 1973, Combes 1991, Jensen \& Mouritsen 1992, Mouritsen \& Jensen

\footnotetext{
•E-mail: x.de-montaudouin@biocean.u-bordeaux.fr
}

1997). However, despite the expected importance of parasitism as a significant factor in the dynamics of host populations, studies of the ecology of digenetic trematodes in marine invertebrates are rare. The questions of how and under which conditions trematode larvae infect their host organisms have been studied in only a relatively few species from marine ecosystems (Styczynska-Jurewicz 1971, Rea \& Erwin 1992, 1995, Combes et al. 1994, Mouritsen \& Jensen 1997). As with other studies involving marine larvae these experiments have mostly been conducted in still water aquaria. During the last decade, the application of flume channels to identifying factors triggering settling and settling efficiency of marine larvae has been widespread (Grassle et al. 1992, André et al. 1993). By adopting this method in infection studies with parasites, a better understanding of parasite dispersal patterns can be achieved. 
The aim of the present work was to investigate whether free larval stages of trematodes (cercariae) are able to locate and infect their host in a mesoscale environment, and to compare their settling efficiency in still and running water. Our hypothesis was that larvae with limited horizontal swimming capabilities have difficulties locating individual hosts in running water. For this investigation we selected Himasthla elongata (Mehlis, 1831) and one of its common second intermediate hosts, the edible cockle Cerastoderma edule (L.). This parasite has been reported to cause mortality in juvenile cockles (Lauckner 1987). H. elongata utilizes Littorina littorea L. as its first intermediate host, several bivalve species (e.g. Cerastoderma edule, Mytilus edulis) as second intermediate hosts and various waterbirds (gulls Larus spp., oystercatcher Haematopus ostralegus, eider duck Somateria mollissima) as definitive hosts (Loos-Frank 1967, Werding 1969, Lauckner 1984). Running and still water experiments were performed in a sea-water recirculating flume.

\section{MATERIALS AND METHODS}

Experimental design. Experiments were carried out in a recirculating water flume (see Vogel 1989) located at Rønbjerg Laboratory, Limfjord (University of Aarhus, Denmark) to compare settling characteristics and transmission efficiency of Himasthla elongata in running water and in still water conditions. The flume was $3.5 \mathrm{~m}$ long, $0.5 \mathrm{~m}$ wide and $0.4 \mathrm{~m}$ deep. The working section measured $0.4 \times 0.5 \mathrm{~m}$ and was situated $2.4 \mathrm{~m}$ downstream from the water entrance. This section was filled with defaunated sand (median grain size = $375 \mu \mathrm{m})$ to a level flush with the flume bottom. This sand came from the supralittoral level of a Limfjord beach, and had been soaked in fresh water for at least $2 \mathrm{~d}$. Seawater $(27 \%$ ) in the flume was adjusted to a height of $14 \mathrm{~cm}$ (Table 1)

Table 1. Physical parameters monitored in the flume during experiments

\begin{tabular}{|lcc|}
\hline & Running water & Still water \\
\hline Medium grain size $(\mu \mathrm{m})$ & 375 & 375 \\
Water depth $(\mathrm{cm})$ & 14 & 14 \\
Salinity $(\%)$ & 28 & 28 \\
Temperature $\left({ }^{\circ} \mathrm{C}\right)$ at start & $20.3(0.3)$ & $19.8(0.2)$ \\
Temperature $\left({ }^{\circ} \mathrm{C}\right)$ at end & $20.0(0.0)$ & $19.7(0.2)$ \\
$\mathrm{O}_{2}$ content $\left(\mathrm{mg} \mathrm{l}^{-1}\right)$ at start & $6.8(0.2)$ & $6.7(0.1)$ \\
$\mathrm{O}_{2}$ content $\left(\mathrm{mg} \mathrm{l}^{-1}\right)$ at end & $7.3(0.2)$ & $5.0(0.6)$ \\
Surface velocity $\left(\mathrm{cm} \mathrm{s}^{-1}\right)$ & 6.0 & 0.0 \\
Shear stress velocity $\left(u . . \mathrm{cm} \mathrm{s}^{-1}\right)$ & 0.3 & 0.0 \\
Roughness Reynolds number & 1.1 & 0.0 \\
\hline
\end{tabular}

In running water experiments, water flow was driven by a single propeller and the water was recirculated between the outlet and the inlet through a PVC tube (diameter $=32 \mathrm{~cm})$. Two collimators $(10 \mathrm{~mm}$ grid diameter) in series homogenized the flow when water entered the flume tank. Between the inlet and the collimators, air was supplied in the water column. Flow speed was measured in the centre of the working section using an ultrasonic velocimeter, Minilab SD-12 (Sensordata). Shear stress velocity $(u$.) at the sediment area was calculated from the logarithmic section of the velocity profile by fitting the velocity function described by the 'law of the wall' (Jumars \& Nowell 1984) (Fig. 1):

$$
U(z)=\left(u_{*} / k\right) \ln \left(z / z_{0}\right)
$$

where $U(z)$ is the mean downstream velocity at height $z$ above the bottom, $z_{0}$ is the boundary roughness and $k$ is the von Karman's constant (0.41). Estimates of $u$. were then used to calculate the roughness Reynolds number, Re. (Nowell \& Jumars 1984):

$$
\mathrm{Re}_{.}=u \cdot k_{\mathrm{s}} / v
$$

where $k_{\mathrm{s}}$ is the bed roughness scale (assimilated as the medium grain size of the sediment, i.e. $375 \mu \mathrm{m}$ ) and $v$ is the kinetic viscosity of seawater $\left(0.01 \mathrm{~cm} \mathrm{~s}^{-1}\right)$.

The surface current velocity above the sediment area was $6 \mathrm{~cm} \mathrm{~s}^{-1}$, corresponding to a shear velocity of 0.26 $\mathrm{cm}^{2} \mathrm{~s}^{-1}$ (Table 1). This shear velocity was calculated within the log layer with 12 points $\left(\mathrm{r}^{2}=0.986\right)$ (Fig. 1). The roughness Reynolds number indicated smooth turbulent flow ( $\mathrm{Re} .<3.5$ ) above the sand area (Nowell \& Jumars 1984). This current regime was selected because it supplied the best velocity profiles in this flume and was within the velocity range of that found in natural environments (Butman 1986, Eckman et al. 1994). However, we recognize that the Rønbjerg flume does not fulfil all recommendations concerning the development of the boundary layer on the side walls and the equilibrium of the bottom boundary layer (Jumars \&

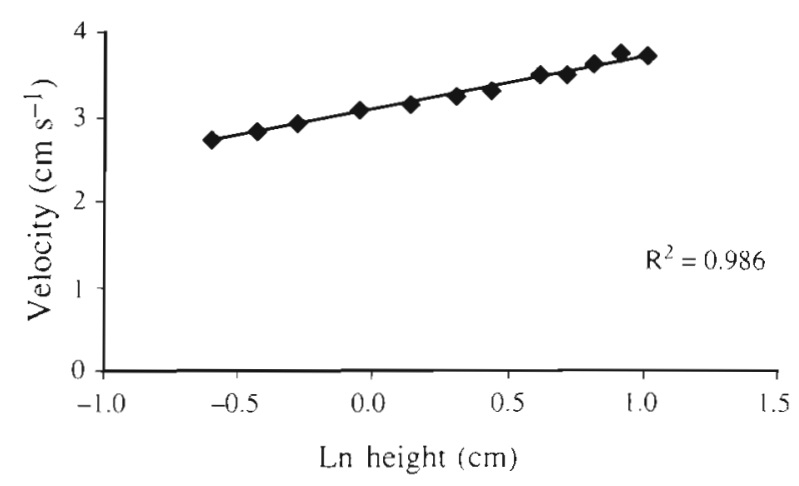

Fig. 1 Relationship between flow velocity and water height (ln) above the bottom of the flume channel $\left(r^{2}=0.986\right)$ 
Nowell 1984, Muschenheim et al. 1986). Therefore, no velocities other than $6 \mathrm{~cm} \mathrm{~s}$ ' and still water were tested.

The still water experiment was performed in the working section of the flume by isolating this part with transparent plastic walls. Air was supplied before each run, but not during the experiment as bubbles created ascending currents. The still water experiment was not considered as a true 'control' but rather as a different treatment. The different flow velocities $\left(0\right.$ and $\left.6 \mathrm{~cm} \mathrm{~s}^{-1}\right)$ also generate differences in the duration of contact between cercariae and the sediment. The importance of this is so far unknown because the behaviour of cercariae in the flume is unknown.

Snails Littorina littorea were collected from Rønbjerg harbour. To distinguish between infected and noninfected snails, each individual was isolated in a dish and exposed to light at $20^{\circ} \mathrm{C}$ for $\sim 1$ to $4 \mathrm{~h}$. This treatment generally induced emergence of cercariae from infected specimens. Snails shedding Himasthla elongata were placed in an aquarium at $15^{\circ} \mathrm{C}$ with $27 \%$ water salinity, and fed with the green algae Ulvae sp. until the start of the experiment. Experimental cockles were sampled on a sand flat at Skallingen, in the Danish Wadden Sea, in November 1997. They were stored in a running seawater system in the laboratory (Ronbjerg), at $6^{\circ} \mathrm{C}$ and $27 \%$ (Table 1 ), and fed with a natural mixture of microalgae. The experiment started in December, 2 wk after the cockles had been collected. Prior to the experiment, cockles from 3 length classes (6-8 $\mathrm{mm}, 8-10 \mathrm{~mm}, 10-12 \mathrm{~mm}$ ) with 20 individuals in each (i.e. a total of 60 cockles) were dissected under a binocular microscope to check metacercarial presence. None of the cockles were infected by $H$. elongata. Consequently, we assumed that the preload of $H$. elongata metacercariae before each experiment was zero.

Before each flume experiment, cockles were measured to obtain 3 length classes $(6-8 \mathrm{~mm}, 8-10 \mathrm{~mm}$, $10-12 \mathrm{~mm}$ ) each consisting of 30 individuals (i.e. a total of 90 cockles per replicate). To acclimatise them slowly to the temperature of the flume water $\left(20^{\circ} \mathrm{C}\right)$ the cockles were placed into static aerated seawater $\left(6^{\circ} \mathrm{C}\right)$ in the flume room where the air temperature was $20^{\circ} \mathrm{C}$, allowing the water to gradually warm up. Shedding of cercariae from infected snails was stimulated by incubating snails under light at $20^{\circ} \mathrm{C}$ for $\sim 1$ to $4 \mathrm{~h}$. A total of 1500 shedded Himasthla elongata ( 1 h old, maximum) were collected with Pasteur pipettes under the binocular microscope and introduced into the flume in five $3.5 \mathrm{~cm}$ diameter petri-dishes filled with seawater. The young age of the cercariae ensures maximum infectivity (Greve 1997). Cockles were distributed randomly over the surface of the sandy area of the flume and kept in still water for 10 min to allow them to burrow before cercariae were added. For each run (replicate) 1500 cercariae were injected into the flume. In running water, cercariae in petri-dishes were introduced $1 \mathrm{~m}$ upstream to the experimental area, and in still water in the middle of the water body. In both situations, petridishes were opened $7 \mathrm{~cm}$ below the water surface and gently shaken to liberate the cercariae.

Both treatments (with and without current) were replicated 4 times and performed under white incandescent light (one $60 \mathrm{~W}$ light source, $2 \mathrm{~m}$ above the flume, providing -1 to $2 \mu \mathrm{E}$ ). Temperature and oxygen concentration were measured at the start and at the end of each run. Each run lasted $20 \mathrm{~h}$; this duration is close to the limit for how long Himasthla elongata can maintain its infectivity at $20^{\circ} \mathrm{C}$ (Greve 1997). This threshold allowed us to replicate the runs every $24 \mathrm{~h}$, without emptying the flume. Before every experiment, fresh water was added to maintain salinity, and water depth of $14 \mathrm{~cm}$. At the end of each of the 8 runs, all cockles were collected and we recorded the position of each of them (i.e. burrowed or not). All the cockles were measured (shell length) and then dissected under a binocular microscope to count encysted cercariae in relation to their position in the organs (foot, mantle and siphons).

Statistical procedure. To compare the number of metacercariae in the experimental cockles as a function of current and individual length, a split-plot ANOVA was performed with hydrodynamics as mainplot (Potvin 1993). Analyses for the different organs (foot, mantle, siphons) or for the whole individual (total) were performed separately. The effect of cockle length on cockle burrowing ability in the sediment was tested with a randomized block ANOVA in which running and still water conditions were separated. The 4 sets of runs (replicates) were treated as blocks in this analysis and cockle length class was the fixed treatment. The variable was the number of unburrowed cockles. Correlation between the infection rates in the different organs was calculated for each length class with the Pearson product-moment test. Prior to ANOVA, homogeneity of variance was tested (Bartlett test). When data were not homogenous, they were log-transformed, which provided homoscedasticity. Normality was assumed (Underwood 1981).

\section{RESULTS}

More than $99 \%$ of the cockles from the Skallingen population were heavily infected with Himasthla interrupta. However, this preload of the experimental animals did not interfere with enumeration of $H$. elongata metacercariae because there is a significant size difference between the 2 Himasthla species. The main purpose of our experiments was to test the ability of cercariae to infect cockles in running water, which should 
Table 2. Parameters of the split-plot ANOVA comparing the number of Himasthla eiongata in the foot, the siphons and the whole specimen (total) of cockles in relation to hydrodynamic conditions (still and running water), and size ( 3 length classes between 6 and $12 \mathrm{~mm}$ ). The main plot consisted of the experimental replicates $(2 \times 4$ runs). Analysis was performed on $\log (x+1)$ transformed data to obtain homoscedasticity. Significant effects $(p<0.05)$ are in bold ns: non-significant $(p>0.05)_{i} \cdot p<0.05_{i} \cdots p<0.001$

\begin{tabular}{|c|c|c|c|c|c|}
\hline Source & df & SS & MS & $F$ & $\mathrm{p}$ \\
\hline \multicolumn{6}{|l|}{ Foot } \\
\hline Current & 1 & 3.98 & 3.98 & 2.58 & $0.160 \mathrm{~ns}$ \\
\hline Main plot (Current & t) 6 & 9.28 & 1.55 & 2.44 & $0.024^{\circ}$ \\
\hline Size & 2 & 193.67 & 96.84 & 112.00 & $0.000^{\cdots} \cdots$ \\
\hline Current $\times$ Size & 2 & 3.44 & 1.72 & 2.72 & $0.067 \mathrm{~ns}$ \\
\hline Ind. (Size) & 87 & 75.22 & 0.86 & 1.37 & $0.020^{\circ}$ \\
\hline Error & 621 & 392.81 & 0.63 & & \\
\hline Total & 719 & 678.41 & & & \\
\hline \multicolumn{6}{|l|}{ Siphons } \\
\hline Current & 1 & 36.69 & 36.39 & 41.41 & $0.001 \cdots$ \\
\hline Main plot (Current) & ) 6 & 5.32 & 0.89 & 1.46 & $0.190 \mathrm{~ns}$ \\
\hline Size & 2 & 39.63 & 19.82 & 30.48 & $0.000 \cdots$ \\
\hline Current $\times$ Size & 2 & 2.73 & 1.36 & 2.25 & $0.107 \mathrm{~ns}$ \\
\hline Ind. (Size) & 87 & 56.55 & 0.65 & 1.07 & $0.321 \mathrm{~ns}$ \\
\hline Error & 621 & 377.09 & 0.61 & & \\
\hline Total & 719 & 518.01 & & & \\
\hline \multicolumn{6}{|l|}{ Total } \\
\hline Current & 1 & 2.51 & 2.51 & 4.10 & $0.089 \mathrm{~ns}$ \\
\hline Main plot (Current) & 6 & 3.68 & 0.61 & 0.92 & $0.482 \mathrm{~ns}$ \\
\hline Size & 2 & 174.53 & 87.26 & 100.50 & $0.000^{\cdots}$ \\
\hline Current $\times$ Size & 2 & 3.11 & 1.56 & 2.33 & $0.098 \mathrm{~ns}$ \\
\hline Ind. (Size) & 87 & 75.54 & 0.87 & 1.30 & $0.044^{\circ}$ \\
\hline Error & 621 & 415.16 & 0.67 & & \\
\hline Total & 719 & 674.53 & & & \\
\hline
\end{tabular}

impair their transmission efficiency. However, there was no significant difference in the total number of $H$. elongata metacercariae between cockles from the still and running water treatments ('Current' term in Table 2, $\mathrm{p}=0.089$ ). More than $90 \%$ of the cockles were infected by $H$. elongata during the experiment and approximately $60 \%$ of the added cercariae were recovered as metacercariae in the cockles from both the still and running water treatments (Table 3). The other experimentally controlled factor, cockle length, had a significant impact $(\mathrm{p}<0.001)$; larger cockles contained more

Table 3. Percentage of cockles ( $\pm 1 \mathrm{SD}$ ) experimentally infected by Himasthla elongata at the end of the experiment and percentage ( \pm 1 SD) of experimentally added $H$. elongata cercariae (1500) recovered as metacercariae in cockles at the end of the experiment

\begin{tabular}{|lccccc|}
\hline Treatment & $\begin{array}{c}\%( \pm 1 \text { SD }) \text { of } \\
\text { infected cockles }\end{array}$ & \multicolumn{3}{c|}{ Foot $( \pm 1$ SD) of encysted cercariae } \\
& $93( \pm 2)$ & $43( \pm 2)$ & $3( \pm 1)$ & $13( \pm 3)$ & $59( \pm 3)$ \\
\hline $\begin{array}{l}\text { Running water } \\
\text { Still water }\end{array}$ & $94( \pm 2)$ & $36( \pm 6)$ & $4( \pm 2)$ & $24( \pm 3)$ & $63( \pm 7)$ \\
\hline
\end{tabular}

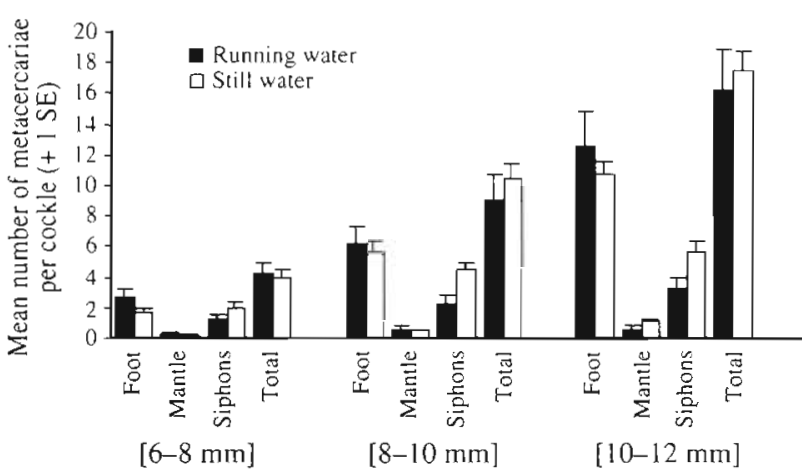

Fig. 2. Numbers (mean + SE) of Himasthla elongata metacercariae in Cerastoderma edule (foot, mantle, siphons, total) as a result of experimental exposure to cercariae in the running water and still water experiments

metacercariae than smaller cockles (Table 2). Cockle individuals from the 3 length classes $(6-8,8-10$ and $10-12 \mathrm{~mm}$ ) contained on average 4,10 and 17 metacercariae. Furthermore, the variability of the infection intensity within each length class provided a significant 'individual within size' term in the ANOVA ( $\mathrm{p}<$ 0.05) (Table 2). Most metacercariae occurred in the foot and some in the siphons (Fig. 2). The main plot within the current displayed a significant difference for the foot (Table 2, p < 0.05), which can only be explained as a moderate effect of the variability of infestation intensity between cockles. Some cockles did not burrow during the experiment. The percentage of non-burrowed cockles was higher in still water $(26 \pm 7 \%, \mathrm{SE})$ than in running water $(9 \pm 1.5 \%, \mathrm{SE})$ $(p<0.05)$. There was no difference between length classes for burrowed and non-burrowed individuals $(p>0.05)$ (Table 4). The difference in the number of unburrowed cockles from still and running water was probably linked to a slight oxygen deficiency and variability within the 4 still water experiments (Table 1). The numbers of $H$. elongata metacercariae were compared in burrowed and non-burrowed cockles (Fig. 3). Generally, there were no significant differences between the infection patterns within these 2 groups. However, for those in the largest length class $(10-12 \mathrm{~mm})$ in running water, significantly more metacercariae were found in the foot of burrowed than of non-burrowed specimens. In the same size class the intensity of metacercariae in non-burrowed cockles was higher in those from still water than in those from running water runs. Correlation analyses between the number of metacercariae in the different tissues indicated that the cercariae infected their specific target tissues randomly, i.e. the foot and the siphons (Table 5). 
Table 4. Parameters of randomized block ANOVA to assess the effect of cockle length ( 3 size classes between 6 and $12 \mathrm{~mm}$ ) on the cockles' ability to burrow in the sediment, in running or still water conditions (ns: $p>0.05 i " p<0.05$ )

\begin{tabular}{|llrrrrc|}
\hline & Source & SS & df & MS & $F$ & p \\
\hline Running water & Block & 7.58 & 3 & 2.53 & 0.91 & $0.49 \mathrm{~ns}$ \\
& Size & 26.00 & 2 & 13.00 & 4.68 & $0.06 \mathrm{~ns}$ \\
& Error & 16.67 & 6 & 2.78 & & \\
Still water & Block & 138.25 & 3 & 46.08 & 5.82 & $0.03 \cdot$ \\
& Size & 10.50 & 2 & 5.25 & 0.66 & $0.55 \mathrm{~ns}$ \\
& Error & 47.50 & 6 & 7.92 & & \\
\hline
\end{tabular}

\section{DISCUSSION}

In both the still water and flume flow experiments approximately $60 \%$ of the added cercariae were recovered as metacercariae inside the experimental cockles. This is comparable to what we have observed previously in petri-dish experiments where we incubated a single cockle with a group of cercariae (Wegeberg 1998). Running water with a free-stream velocity of $6 \mathrm{~cm} \mathrm{~s}^{-1}$ does not impair the ability of Himasthla elongata to locate a host individual. Unlike settling larvae of free-living organisms searching for a suitable substratum, trematode larvae must locate another organism. For example, cockle larvae must avoid being inhaled by adult conspecifics, whereas inhalation by the cockle may represent part of the transmission strategy of trematode larvae. In the following discussion, one can consider 2 possible explanations for the high infection rates: (1) active larval choice or (2) passive accumulation in cockles due to their pumping activity. Experience from still water aquaria suggests that cercariae from Himasthla spp., after emergence from their snail host, swim actively in the water column. The propulsive force is created by the vigorously moving tail, and consequently cercariae rise in the water column. When the tail ceases to beat, the cercaria sinks slowly for a short period (Stunkard 1938, Loos-Frank 1967, Werding 1969, Chapman \& Wilson 1973, authors' unpubl. obs.). According to Werding (1969) and our own observations (unpubl.) H. elongata cercariae in still water mostly remain close to the bottom, perhaps indicating positive geotropism. Apparently, cercariae do not exhibit specific host taxis behaviour, swimming erratically within the water column. There is no report of chemotactic behaviour in Himasthla species, in contrast to other members of the family Echinostomatidae (McCarthy 1990). Examples of cercariae exhibiting chemotactic behaviour are limited to parasite-host systems in which the second intermediate host is a gastropod (Fried \& King 1989, Haas et al. 1995). Campbell (1997) demonstrated that cercariae of Cotylurus flabel-
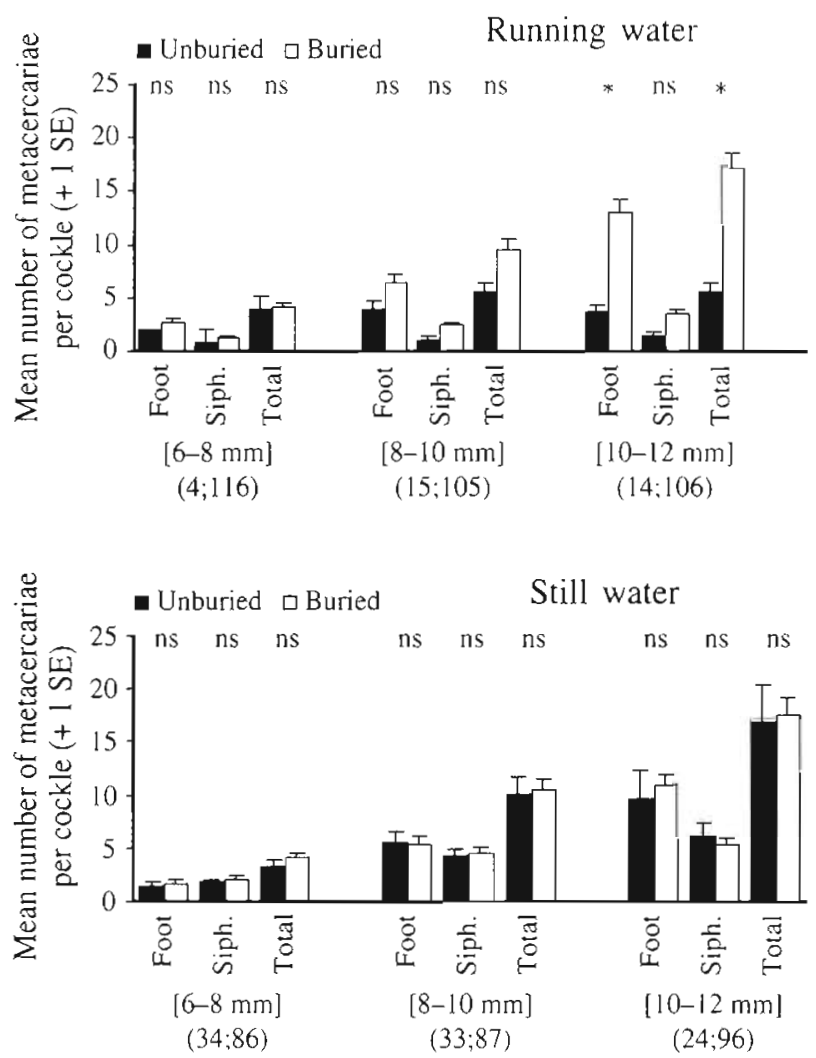

Fig. 3. Numbers (mean + SE) of Himasthla elongata metacercariae in Cerastoderma edule (foot, siphons, total) in burrowed and non-burrowed cockles from running and still water treatments, respectively. The numbers of burrowed and non-burrowed cockles are indicated in parentheses. Differences between burrowed and non-burrowed cockles were tested by using a Student $t$-test (ns: non-significant, $\mathrm{p}>0.05$;

$$
* \text { : significant, } p<0.05 \text { ) }
$$

Table 5. Product-moment correlation coefficients of Pearson matrix between number of Himasthla elongata metacercariae in the foot (elongfoot), siphons (elongsiph) and total tissues (elongtotal) of Cerastoderma edule of 3 length classes ( $\cdots p<$ 0.001 ). The upper right part of each matrix displays results from the running water experiment and the lower left part from still water experiment. Each correlation was calculated from 120 cockles (i.e. 30 cockles per replicate and length class, multiplied by 4 replicates per treatment)

\begin{tabular}{|c|c|c|c|c|}
\hline & & elongfoot & elongsiph & elongtotal \\
\hline $6-8 \mathrm{~mm}$ & $\begin{array}{l}\text { elongfoot } \\
\text { elongsiph } \\
\text { elongtotal }\end{array}$ & $\begin{array}{c}- \\
+0.51 \cdots \\
+0.87 \cdots\end{array}$ & $\begin{array}{c}+0.57 \cdots \\
- \\
+0.85 \cdots\end{array}$ & $\begin{array}{c}+0.88 \cdots \\
+0.89 \cdots \\
-\end{array}$ \\
\hline $8-10 \mathrm{~mm}$ & $\begin{array}{l}\text { elongfoot } \\
\text { elongsiph } \\
\text { elongtotal }\end{array}$ & $\begin{array}{c}- \\
+0.44 \cdots \\
+0.88 \cdots\end{array}$ & $\begin{array}{c}+0.74 \cdots \\
- \\
+0.79 \cdots\end{array}$ & $\begin{array}{c}+0.90 \cdots \\
+0.96 \cdots \\
-\end{array}$ \\
\hline $10-12 \mathrm{~mm}$ & $\begin{array}{l}\text { elongfoot } \\
\text { elongsiph } \\
\text { elongtotal }\end{array}$ & $\begin{array}{c}- \\
+0.48 \cdots \\
+0.91 \cdots\end{array}$ & $\begin{array}{c}+0.33 \cdots \\
- \\
+0.78 \cdots\end{array}$ & $\begin{array}{c}+0.95 \cdots \\
+0.60 \cdots \\
-\end{array}$ \\
\hline
\end{tabular}


liformis (Strigeidae) have a chemo-positive attraction to undetermined substances from snails and locate their host at distances up to $1.2 \mathrm{~m}$.

Considering the reported maximum horizontal swimming velocities exhibited by Echinostomatid cercariae (3.6 $\mathrm{mm} \mathrm{s}^{-1}$; Meyrowitsch et al. 1991), cercarial swimming rates may only exceed water velocity in the most near-bottom water layers (up to $400 \mu \mathrm{m}$ above the bottom in our flume experiment; calculated from formulae for the thickness of the viscous sublayer and flow velocity as a function of distance from the bottom in Butman 1986). Loos-Frank (1967) reported that Himasthla spp. cercariae, after contacting a potential host, cease swimming and show inch-worm movements (thigmotactic behaviour). There is generally no indication that cercariae are attracted by secretions from potential host individuals. The behavioural adaptations of Himasthla spp. cercariae are independent of the presence of the host but may serve to localise themselves in the appropriate host space (sensu Combes et al. 1994). Apparently, cercariae do not actively locate their host.

The infection of cockles could result from random encounters between a cercaria and a cockle or could be mediated by the pumping activity of the cockle. Observations in still water experiments have indicated that Himasthla spp. cercariae may infect their bivalve host either through the inhalant siphon or by attacking the foot-visceral mass directly when it is exposed (authors' pers. obs.). However, it is not obvious how a cercaria could enter a host individual burrowed in sediment, unless it encysts itself on the exposed siphons, as actually was the case in non-burrowed cockles from the still water experiment. For a non-burrowed cockle, direct attack of the foot is a possible infection route (Loos-Frank 1967). Nonetheless, our data indicated that non-burrowed cockles (the largest size class, running water) had a lower intensity of metacercariae than burrowed cockles. These observations do not support the hypothesis that the foot and exposed part of the visceral mass are direct targets for cercariae. However, the higher intensity of metacercariae in non-burrowed cockles from the still water experiment than in those from the flow experiment suggest that cercariae may have more success in attacking the fleshy parts directly in still water than in flowing water, which could hinder direct attachment to exposed body parts of the cockle. Due to the water flow, cercariae may not attach directly to exposed body parts in running water (Fig. 4). Cercaria approaching or touching a cockle siphon elicit a closing response from the cockle. LoosFrank (1967) observed that Himasthla spp. cercaria were inhaled through the siphon of bivalves but were rapidly expelled. She concluded that a direct attack on the foot-visceral mass promoted by the thigmotactic
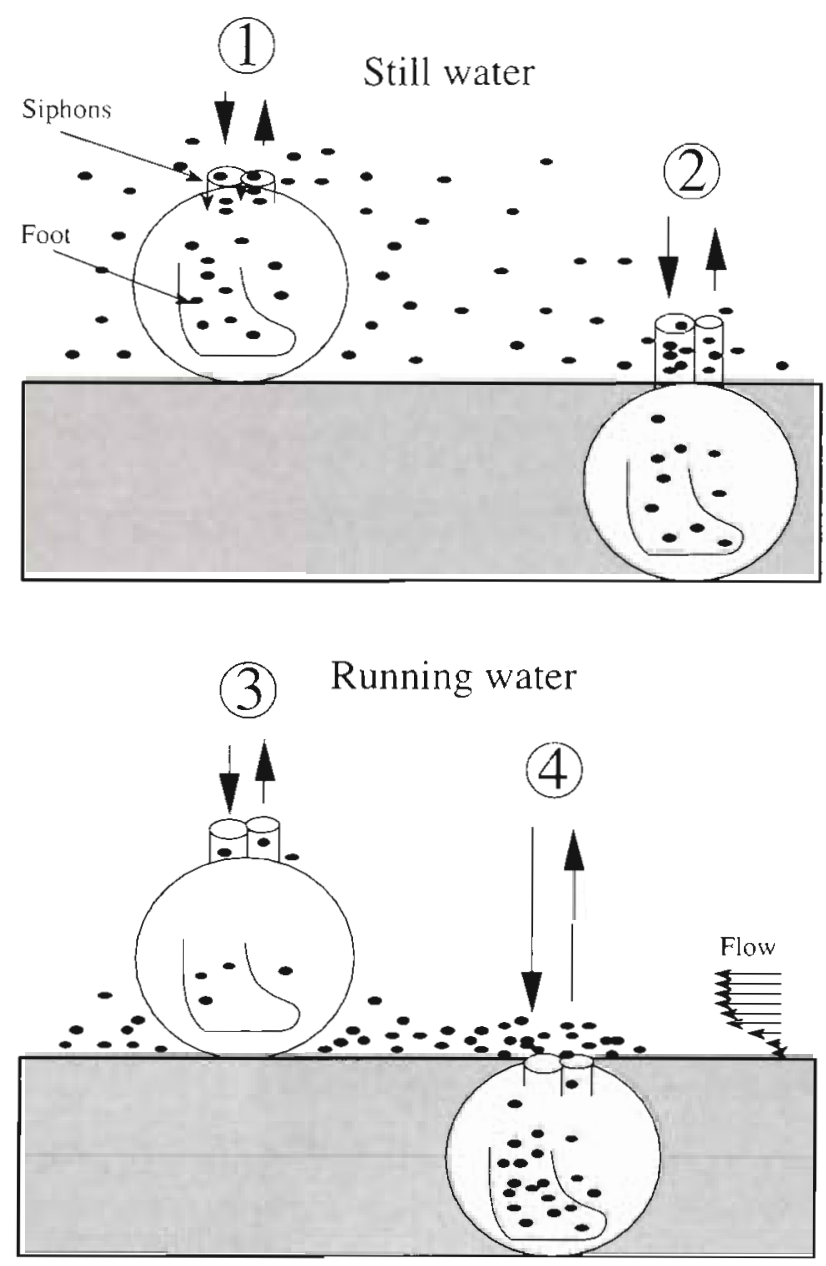

Fig. 4. Sources of infection routes of Cerastoderma edule by Himasthla elongata in still and running water according to the cockles' position (burrowed or non-burrowed). Dots represent cercariae, and vertical arrows the velocity of the current through siphons. In still water, non-burrowed cockles (1) are totally exposed to cercariae, and burrowed cockles (2) extend their siphons as a reaction to oxygen deficit. In running water, cercariae can be trapped near the bottom, which prevents them from being inhaled by larger non-burrowed cockles (3). Burrowed cockles (4), in contrast, would inhale cercariae due to their high pumping rate

behaviour, already described, was a more successful infection route. However, Wegeberg (1998) observed that Himasthla cercariae that managed to infect juvenile cockles (shell length 1.5 to $12 \mathrm{~mm}$ ) in small aquaria primarily entered the mantle cavity via the inhalant water current.

The water column in the still water experiment was partly stirred by combined effects of the excurrent jets and of the inhalant flow of water created by the experimental population of suspension-feeders. The excurrent jet of water may reach a height of $35 \mathrm{~cm}$ and the flow velocity in the central part of a jet of water may attain $70 \mathrm{~mm} \mathrm{~s}^{-1}$ (André et al. 1993). Inhalant flow 
velocities were inversely proportional to the square of the distance from the siphon opening, and generally had little impact at a distance of more than $1 \mathrm{~cm}$ from the siphon (André et al. 1993). Apparently, there are no precise measurements of the swimming velocity of Himasthla spp. larvae; some other Echinostomatid larvae can reach a maximum speed of $-3.6 \mathrm{~mm} \mathrm{~s}^{-1}$ (newly emerged cercariae; Meyrowitsch et al. 1991).

In conclusion, the behaviour of cercariae does not actively direct them towards a potential host. In contrast, passive inhalation by cockles aided by cercariae geotactic behaviour is the most likely mode for cercariae to enter the mantle cavity, where penetration can occur. The question then is whether the pumping rate of the experimental cockle populations actually could be responsible for the high prevalence and intensity of metacercariae in cockles?

In the still water experiment, 90 cockles were in an aquarium containing $28 \mathrm{l}$ of seawater. Based on information given in Vahl (1972) and considering the 3 size groups represented among the cockles it is estimated that this experimental population has a pumping capacity of $10.5 \mathrm{l} \mathrm{h}^{-1}$ or $210 \mathrm{l}$ during 1 experiment $(20 \mathrm{~h})$. As the experiments were run at $20^{\circ} \mathrm{C}$ and the pumping rates reported in Vahl (1972) were measured at $10^{\circ} \mathrm{C}$, we anticipate that the cockles would have had a considerably higher pumping rate than that estimated above. The cockles must therefore have refiltered the water at least 7 times during 1 experiment. For this reason, it is understandable that there was very high infection success in the still water treatment, assuming that cercariae enter through the inhalant siphon. The likelihood of this infection route is supported by the fact that the largest cockles $111 \mathrm{~mm}$ in shell length) had the highest metacercariae density as they are predicted to pump more than twice the amount of water pumped by the smallest cockles ( $7 \mathrm{~mm}$ in shell length) (166 $\mathrm{ml} \mathrm{h}^{-1}$ vs $70 \mathrm{ml} \mathrm{h}^{-1}$ according to Vahl 1972). According to André et al. (1993), cockles show the same regular feeding rhythm with continuous pumping in both still and flowing water. However, the amount of water in the 2 systems was different; our flume tank contained -360 l of seawater. Assuming that cockles have the same pumping capacity as in still water, only half of this amount of water passed through the cockles during the $20 \mathrm{~h}$ experiment. We do not know how cercariae are distributed in the water column in the 2 different scenarios, although, in still water, they are believed to stay close to the bottom, as observed in small dishes (authors' unpubl. obs.). In the flume experiment, this is probably also true. There could even be a tendency for them to become trapped in the viscous sublayer and drift in a streamwise direction as reported for cockle larvae (André et al. 1993). To cockle larvae - as reported by
André at al. (1993)-entrapment here means high predation risk. Only a few cockle larvae in their experiment managed to escape the inhalation pressure established by adult cockles in an experimental set-up very similar to the one presented here except that the adult cockles were older and larger (15 to $43 \mathrm{~mm}$ ). Due to the observed geopositive response, we expect that cercariae generally are situated in the water layer inhaled by cockles both in the still water and flowing water experiments. This could also explain the high infection rates achieved in both scenarios. Rough calculations indicate that a surviving cercaria may have cycled around the flume and thereby passed the working area 617 times during the experimental period of $20 \mathrm{~h}$ (flume length $7 \mathrm{~m}$; free-stream velocity of $6 \mathrm{~cm}$ $\left.\mathrm{s}^{-1}\right)$. Even if cercariae are infective for only $10 \mathrm{~h}$, which occurs with Echinostoma capronia (Meyrowitsch et al. 1991), 'surviving' cercaria will have passed the cockle sink more than 300 times. The potential for inhalation by a cockle will be high under these conditions. The transmission method adopted by Himasthla elongata cercariae to capitalise on the feeding behaviour of their bivalve hosts seems very efficient.

Our study suggests that Himasthla elongata cercariae may spread with water flow to host populations situated outside the immediate surroundings of the snail host from which they were shed. With a water flow of $6 \mathrm{~cm} \mathrm{~s}^{-1}$ the scale of potential dispersal is at least a few hundred metres presuming that the cercariae retain their infectivity for at least 10 to $12 \mathrm{~h}$. We are unable to state whether the cercariae in our flume experiment infected cockles during their first passage or if they passed several times before having any success, and further studies are needed to reveal the dispersal potential of the studied trematode by including higher water flow speeds and examining their distribution in the water body. We are also aware that our flume design provided very steady hydrodynamic conditions and did not include effect of waves, substrate heterogeneity and stronger currents on $H$. elongata dispersal. Still it seems conservative to conclude that snails like Littorina littorea (first intermediate host) occurring in one zone along an intertidal gradient could still be the source of $H$. elongata propagules infecting bivalves (second intermediate hosts) in another tidal zone and that transmission events are not restricted to small water bodies.

Acknowledgements. Thanks to Mrs $V$ Huet for her valuable help in the flow velocity measurements and to Dr J. T. Christensen for his warm hospitality at the Marine Station of Rønbjerg. The authors are also grateful to Dr D. Welsh, who kindly corrected the English and to the 3 referees who significantly improved the manuscript. The study was supported by the Carlsberg Foundation (grant to K.T.J.) and was also a contribution to the French programme on recruitment (PNDR). 


\section{LITERATURE CITED}

André C, Jonsson PR, Lindegarth M (1993) Predation on settling bivalve larvae by benthic suspension feeders: the role of hydrodynamics and larval behaviour. Mar Ecol Prog Ser 97:183-192

Butman CA (1986) Larval settlement of soft-sediment invertebrates; some predictions based on an analysis of near bottom velocity profiles. In: Nihoul JCJ (ed) Marine interfaces ecohydrodynamics. Elsevier Oceanography Series, 42. Elsevier, Amsterdam, p 487-513

Campbell RA (1997) Host-finding behaviour of Cotylurus flabelliformis (Trematoda: Strigeidae) cercariae for snail hosts. Folia Parasitologia 44:199-204

Chapman HD, Wilson RA (1973) The propulsion of the cercariae of Himasthla secunda (Nicoll) and Cryptocotyle lingua. Parasitology 67:1-15

Combes $C$ (1991) Ethological aspects of parasite transmission. Am Nat 138:866-880

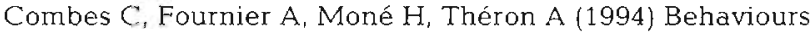
in trematode cercariae that enhance parasite transmission: patterns and processes. Parasitology 109(Suppl):57-67

Eckman JE, Werner FE, Gross TF (1994) Modelling some effects of behaviour on larval settlement in a turbulent boundary layer. Deep-Sea Res II 41(1):185-208

Fried B, King BW (1989) Attraction of Echinostoma revolutum to Biomphalaria glabrata dialysate. J Parasitol 75(1):55-57

Grassle JP, Snelgrove PVR, Butman CA (1992) Larval habitat choice in still water and flume flows by the opportunistic bivalve Mulinia lateralis. Neth J Sea Res 30:33-44

Greve $T$ (1997) Interaktioner mellem den marine parasit Himasthla elongata og dennes anden mellemvert den almindelige hjertemusling (Cerastoderma edule). MSc thesis, Department of Marine Ecology, University of Aarhus

Haas W, Körner M, Hutterer E, Wegner M, Haberl B (1995) Finding and recognition of the snail intermediate hosts by 3 species of echinostome cercariae. Parasitology 110 . $133-142$

HuIscher JB (1973) Burying-depth and trematode infection in Macoma baltica. Neth J Sea Res 6(1-2):141-156

Jensen KT, Mouritsen K (1992) Mass mortality in two common soft-bottom invertebrates, Hydrobia ulvae and Corophium volutator - the possible role of trematodes. Helgol Meeresunters 46:329-339

Johnson PT (1968) Population crashes in the bean clam, Donax gouldi, and their significance to the study of mass mortality in other marine invertebrates. J Invertebr Pathol 12:349-358

Jonsson R, André C (1992) Mass mortality of the bivalve Cerastoderma edule on the Swedish west coast caused by infestation with digenean trematode Cercaria cerastodermae I. Ophelia 36(2):151-157

Jumars PA, Nowell ARM (1984) Fluid and sediment dynamic effects on marine benthic community structure. Am Zool $24: 45-55$

Lauckner G (1971) Zur Trematodenfauna der Herzmuscheln Cardium edule und Cardium lamarcki. Helgol Wiss Meeresunters 22:377-400

Lauckner G (1983) Diseases of Mollusca: Bivalvia. In: Kinne $O$ (ed) Diseases of marine animals. Biologische Anstalt Helgoland, Hamburg, p 477-961

Lauckner G (1984) Impact of trematode parasitism on the fauna of a North Sea tidal flat. Helgol Meeresunters 37 : $185-199$

Lauckner G (1987) Effects of parasites on juvenile Wadden
Sea invertebrates. In: Tougaard $S$, Asbirk $S$ (eds) Proc 5th Int Wadden Sea Symp. The National Forest and Nature Agency and the Museum of Fisheries and Shipping, p $103-121$

Lauckner G (1994). Parasiten als bestandsregulierender Faktor im Watt. In: Lozán JL, Rachor E, Reise K, Westernhagen $H \quad v$, Lenz $W$ (eds) Warnsignale aus dem Wattenmeer. Blackwell Wissenschafts-Verlag, Berlin, p 144-149

Loos-Frank B (1967) Experimentelle Untersuchungen über Bau, Entwicklung und Systematik der Himasthlinae (Trematoda, Echinostomatidae) des Nordseeraumes. Z Parasitenkd 28:299-351

McCarthy AM (1990) The influence of second intermediate host dispersion pattern upon the transmission of cercariae of Echinoparyphium recurvatum (Digenea: Echinostomatidae). Parasitology 101:43-47

Meyrowitsch D, Christensen Nø, Hindsbo O (1991) Effects of temperature and host density on the snail-finding capacity of cercariae of Echinostoma caproni (Digenea: Echinostomatidae). Parasitology 102:391-395

Mouritsen KN, Jensen KT (1997) Parasite transmission between soft-bottom invertebrates: temperature mediated infection rates and mortality in Corophium volutator. Mar Ecol Prog Ser 151:123-134

Muschenheim DK, Grant J, Mills EL (1986) Flumes for benthic ecologists: theory, construction and practice. Mar Ecol Prog Ser 5:141-149

Nowell ARM, Jumars PA (1984) Flow environments of aquatic benthos. Annu Rev Ecol Syst 15:303-328

Potvin C (1993) ANOVA: experiments in controlled environments. In: Scheiner M, Gurewitch J (eds) Design and analysis of ecological experiments. Chapman \& Hall, New York, p 46-68

Rea JG, Erwin SWB (1992) The effect of age, temperature. light quantity and wave length on the swimming behaviour of the cercariae of Cryptocotyle lingua (Digenea: Heterophydae). Parasitology 105:131-137

Rea JG, Erwin SWB (1995) The effect of age, temperature and shadow stimuli on activity patterns of the cercariae of Cryptocotyle lingua (Digenea: Heterophydae). Parasitology 110:95-101

Sousa WP (1991) Can models of soft-sediment community structure be complete without parasites? Am Zool 31: $821-830$

Stunkard HR (1938) The morphology and life cycle of the trematode Himasthla quissetensis (Miller and Northup. 1926). Biol Bull (Woods Hole) 75:145-165

Styczynska-Jurewicz E (1971) Tolerance to salinity in some marine and fresh-water cercariae. Acta Parasitol Pol 19: $257-268$

Underwood AJ (1981) Techniques of analysis of variance in experimental marine biology and ecology. Oceanogr Mar Biol Annu Rev 19:513-605

Vahl O (1972) Porosity of the gill, oxygen consumption and pumping rate in Cardium edule (L.) (Bivalvia). Ophelia 10:109-118

Vogel S (1989) Life in moving fluid - the physical biology of flow. Princeton University Press, New Jersey

Wegeberg AM (1998) Digene trematoders (Echinostomatidae) infektionsøkologi og effekt pă Cerastoderma edule. MSc thesis, Dpet of Marine Ecology, Univ of Aarhus

Werding B (1969) Morphologie, Entwicklung und Ökologie digener Trematoden-Larven der Strandschnecke Littorina littorea. Mar Biol 3:306-333

Submitted: December 6, 1997; Accepted: May 26, 1998

Proofs received from author(s): August 17, 1998 